\title{
The effect of service quality on customer satisfaction in fitness firms
}

\author{
Suja Pradeep ${ }^{a^{*}}$, Vanaja Vadakepat ${ }^{\mathrm{b}}$ and D. Rajasenan ${ }^{\mathrm{c}}$
}

${ }^{a}$ Khawarizmi International College Abu Dhabi, United Arab Emirates

${ }^{b}$ New York Institute of Technology, ABU DHABI, United Arab Emirates

${ }^{c}$ Centre for the Study of Social Exclusion and Inclusive Policy CUSAT, Kochi, India

\section{H R O N I C L E}

\section{Article history:}

Received: October 16, 2019

Received in revised format:

January 302020

Accepted: February 10, 2020

Available online:

February 10, 2020

Keywords:

Service Quality

Customer Satisfaction

Customer Retention

Fitness Industry

UAE Market

Abu Dhabi

\section{A B S T R A C T}

The economic downturn, with a weakening oil market, resulted in the growth of divergent businesses that led to competition between destination-branded hotels and non-hotel-based firms in the fitness sector in the United Arab Emirates. Since hotel-based fitness firms have targeted both residents and tourists, the declining customer inflows have alarmed non-hotel-based fitness firms, leading to explore the market and appraise their service qualities, particularly given that their customers have experienced unexpected reductions in their discretionary spending habits. This paper analyzes factors in customers' perception of service quality and its relation to customer satisfaction and retention. A sample of 186 member-customers was randomly selected from all non-hotel-based fitness firms functioning in Abu Dhabi. The primary data were collected through surveys and interviews. Respondents prioritized price, quality, hygiene and safety as major factors when assessing service quality. Although a high service quality index score and customer satisfaction indicated the drive for customer retention, the steady-state matrix apparent in the second year in a Markov analysis suggests that firms focus on improvising their marketing mix to increase customers' spending time in fitness centers and maximize customers' satisfaction with the main purpose of their visit, their own wellbeing and stress reduction. This study fills a research gap and helps fitness firms understand the importance of appraising customers' perceptions of service quality in a downswing market, and of devising niche strategies to gain competitive advantage.

\section{Introduction}

Economic growth and better living standards encourage people to prioritize fitness and wellness programs as essential activities (Ma, 2011). However, if the consequences of economic slowdown affect the performance of all industries in a market, then business cycle contractions are also reflected in the performance of fitness and wellness firms (Dupuis, 2019). The fitness and wellness sector in the United Arab Emirates (UAE) are affected by the current sluggish economy. For instance, the recent plunge in oil prices and a weakened consumer purchasing power in local markets has resulted in the collapse of many businesses and job opportunities in the Emirates. This has deeply impacted the living standards of expatriates, who comprise around 80 percent of the total UAE population (GMI, 2019). During times of economic crisis, consumers tend to alter the priorities of their consumption behavior, resulting in them considering health and wellness to be trivial (Thompson, 2019). Economic downturns have, therefore, deleterious consequences for the fitness, tourism and health sectors in the UAE, as more than 75 percent of the customer profiles of these sectors consist of expatriates (Dubai Economy, 2018). A report by Kerr (2019) on the current state of this business in the Emirates market states that the lack of constant customer inflows to fitness and wellness businesses was due to the exit of better-paid expatriates from the Emirates, to sudden job losses, or to the unexpected and the concomitant drop in discretionary spending habits. Whatever may be the reasons, the impact of this economic collapse on fitness and wellness businesses has resulted in a fall in their income.

* Corresponding author

E-mail address: suja.pradeep@khawarizmi.com (S. Pradeep) 
In the UAE, the two main types of firms engaged in health-promoting fitness and wellness programs are hotel-based and nonhotel-based spas, gyms and fitness and wellness centers targeting UAE residents and global tourists. Although the Global Wellness Institute (2016) and IMTJ (2015) have reported a rapid growth in the wellness tourism markets in the Middle East and North African countries, and McGroarty (2017) found that the UAE market in wellness tourism grew 17.9\% from 2012 to 2017, the economy in the Middle Eastern region remains uncertain (Abbas, 2019). Statistics from the tourism department indicate a 9.8 percent increase in visitors to the UAE during 2018-19 (Algethami, 2013), and, as part of the promotion of destination marketing, the hotel-based fitness and wellness centers are enjoying an increase in visitors; however, as tourists or non-residents, these visitors are not permanent customers. Consequently, many of these hotel-based fitness centers are now also targeting UAE residents with heavy promotion strategies, price discounts and weekend vacation packages, with the aim of gaining market share and achieving long-term business sustainability. Customers' positive responses to these offers, along with their high expectations of the service quality offered by these hotels that have a high brand image, are a competitive advantage enjoyed by hotel-based fitness centers and a challenge to non-hotel-based fitness firms. Given this, non-hotel-based fitness firms need to learn about and satisfy customers' expectations (Parasuraman et al., 1988) in order to survive economic impacts and competition. An appraisal of service quality is, therefore, essential for these firms so that they can market the true value customers expect to get after using the firms' products and services (Economic Times, 2016).

Although there is a lot of information available both on the challenges faced by fitness centers and on service quality assessments at a global level, little attention has been given to understanding consumers' perceptions of the quality of services offered by the privately owned non-hotel-based fitness firms in the UAE market. Accordingly, a market analysis of UAE residents' perceptions of the service quality of privately owned non-hotel-based fitness centers is important for these firms to acquire a competitive edge over the large-scale hotel-based fitness and wellness businesses. The existing literature gap confirms the under-exploration of this area in the UAE market, so the aim of this paper is to fill this research gap by assessing customers' perception of service quality and understanding the link between service quality, customer satisfaction and customer retention. To do this, the paper explores the factors that influence customers' assessment of service quality.

Previous researchers have offered several definitions of service quality (Wisniewski, 2001; Sidin et al., 2001; Caruana; 2002; Nath \& Zheng, 2004; Reza et al., 2016) and have highlighted the need to assess service quality, especially in the service sectors. In line with the study by Kaul $(2005$, p. 3), this paper identifies the assessment of service quality in the fitness sector as a significant tool for increasing the value of the products and services offered by fitness firms, and consequently for ensuring the maximum satisfaction of their customers and thereby retaining those customers.

This paper is organized as follows. Section 2 presents the available literature on service quality, customer satisfaction, the challenges and opportunities faced by the fitness industry, and a profile of this sector in the UAE market. The methodology is described in Section 3, Section 4 presents the analysis and discussion, and Section 5 presents a summary and conclusion.

\section{Literature Review}

Feedback on service quality and customer satisfaction is very important for businesses to compete in markets and to grow. In order to have a sustainable competitive advantage, service-based companies have to excel in the services they offer (Asubonteng et al., 1996). Parasuraman et al. (1985, p.49) view service quality as "the discrepancy between consumers' perceptions of services offered by a particular firm and their expectations about firms offering such services." Hence, if a customer perceives services to be below his or her expectations, he or she is unsatisfied; and if the customer's perception of the service meets or exceeds his or her expectation, then he or she is satisfied (Daniel \& Berinyuy, 2010). Therefore, the overall assessment of the services offered by a firm to its customer is critical for the firm's growth (Sureshchandar et al., 2002; Douglas \& Connor, 2003; Saravanan \& Rao, 2007; Eshghi et al., 2008). Service according to Johns (1999) is firm's performance, output, offering or process and is the result of differential treatment the firms follow on the basis of their business nature. Given this, some studies claim that it is hard to assess the service performance of a firm that is exclusively engaged in intangible products, because of the difficulty of defining the intangible nature of the various products offered by the business (Douglas \& Connor, 2003; Eshghi et al., 2008; Daniel \& Berinyuy, 2010). For instance, Feigenbaum (1986) argues that quality is the sole criterion used for assessment in service marketing, whereas Juran and Godfrey (1999) views appraisal of service quality in terms of product performance resulting in customer satisfaction. Therefore, different perceptions on assessing and appraising service quality and customer satisfaction in an organization (Sokhan et al., 2018) are challenges both for marketers and for researchers.

\subsection{Service quality and marketing mix for fitness firms}

Given the intangible nature of the products offered by the fitness firms, the appraisal of the service quality is closely linked to its marketing mix. For instance, the concept of product for a fitness firm is associated with two factors: the intangible product, which is offered in terms of the service; and the tangible products, which are used to provide services to the customers. These tangible products include exercise equipment and other accessories that are necessary for the services offered by these firms. Both tangible and intangible factors equally and concurrently contribute to the service quality. 
Price is the amount paid by customers for the value of tangible and intangible products offered by the fitness firms. In the current economic downturn, the impact of pricing is significant for every customer in his or her selection of a fitness firm. Discounts and free training packages are some of the significant contributors to customers' decisions to continue or not with their fitness service providers (interview, 3 September 2019). Kotler and Keller (2015), and Jobber and Chadwick (2016) argue that price significantly influences the customers' decisions.

The concept of place indicates the availability of the product to the customer (Pride and Ferrell, 2012). In the case of fitness firms, their location and parking amenities are the two major factors that influence UAE residents. In an interview, customers are of the view that closeness to their residence and car parking are the two factors that influence their choice of a gym or fitness center (interview, 25 September 2019).

Promotion, as a relevant marketing communication, is the process of engaging in communication with customers (Pride and Ferrell, 2012). In the case of the fitness industry, adopting all channels of communication with the customers is essential for reaching a firm's targets in a technologically advanced market like the UAE. With the enhancement of digital marketing, many global organizations inspire customers and tourists by promoting online their experiential marketing and engagement marketing strategies, so it is time for fitness firms to re-evaluate their promotional strategies and communication channels to reach out both to their existing customers and to potential customers.

A loyal customer who is willing to repurchase a product from the same firm, despite having an alternative option, is not only willing to spend money for the services, but is also able to recommend his or her fitness centers to new customers by providing sincere feedback (Nuseir \& Madanat, 2015). Therefore, a strong customer-oriented marketing mix inspires customers to stay loyal to their fitness centers, and the fitness firms can use this loyalty to attract new customers (Ferguson \& Brohaugh, 2008). Many customers in an interview are of the view that they are capable of understanding their own wellness and fitness requirements but that they do not know what fulfilling those requirements is worth to them (interview, 10 August 2019). This lack of customers' understanding emphasizes as an opportunity for the fitness centers to demonstrate convincingly to the customers the value of what the firm can provide them with. Thus, creating value for their service by meeting customers' expectations helps the firms achieve customer satisfaction, customer retention, and the attraction of new customers.

\subsection{Fitness industry in the UAE market}

In light of the above studies, this paper analyzes the position and the resultant dynamics of non-hotel-based fitness firms in the UAE economy. In contrast to the report of economic tensions in the UAE (Rahman, 2012; Algethami, 2013; Abbas, 2019; Kerr, 2019), recent data posit that the UAE has shown robustness in the fitness sector as there has been a record increase in the number of tourists travelling to the UAE for wellness-related services (DOTW news, 2017). According to McGroarty (2017), market growth in tourism and wellness tourism services has been 17.9 percent and 31 percent, respectively, in comparison to other Gulf Cooperation Council countries. However, these statistics mainly relate to tourists who were targeted by five-star hotels that offer fitness and wellness services as part of their vacation or tour packages.

With regard to UAE residents, in the context of the current economic crisis their choice of gym is connected to their disposable income. This has a direct link to the value they expect for the price they pay for tangible and intangible services, including the skill of the service providers and the quality of physical equipment. Despite the competitive promotional offers from the non-hotel-based fitness centers in the market of the UAE capital, Abu Dhabi, most of these fitness firms' businesses are moving slow in the market. In this complex market situation, there is no guarantee that new customer inflow to these fitness firms will increase unless the firms attempt to validate the market and update their marketing mix to survive competition. In light of the above discussion, this study stresses the importance for UAE fitness firms to appraise their service quality so that they can develop a niche strategy to secure competitive advantage. This signifies the scope of this paper.

\subsection{Assessment of service quality}

Service quality assessment is considered a prerequisite for understanding the position of various firms and industries, particularly in the case of the banking, insurance and finance sectors, which do not depend on a unique model for assessment and evaluation. The types of models that are in use to assess service quality vary based on the nature of the industry under evaluation (Nitin et al., 2005). A positive perception of service quality is an amber light showing that the coast is clear, and the industry or firm can take voyages without any risk (Prentice, 2013). This is an indication of customer satisfaction and retention (Mahalakshmi \& Saravanaraj, 2011). For most firms in the sports and recreation/fitness industry, the most suitable analytical model is the Scale of Service Quality in Recreational Sports using the framework developed by Ko and Pastore (2004). However, several analytical frameworks that use varying models are available for measuring service quality in the fitness sector, such as the model of Chelladurai et al. (1987), which uses the Scale of Attributes of Fitness Services; and Chang and Chelladurai's (2003) model, which uses the Scale of Quality in Fitness Centres. A seminal model is Lam et al.'s (2005) Service Quality Assessment Scale. Another model with a high currency for measuring the service quality of fitness centers is the Service Quality Scale for Fitness Centers developed by Yildiz (2011), which has four dimensions - personnel, physical environment, supporting services and program - that link with 25 sub-dimensions. The methodology of the present research, as 
discussed in the next section, drew on the above literature review and acknowledged the service quality assessment models developed by Ruseva et al. (2015) and Gonçalves et al. (2014).

\section{Methodology}

The data for the study was collected through a primary survey, which was administered by distributing the questionnaire to 186 randomly selected member-customers from all the non-hotel-based fitness firm centers operating in the Abu Dhabi central capital city. The data included information on (i) the minutes/hours spent by the respondents in the fitness center to ascertain the level of importance they gave to fitness services, with an aim to review the efficiency of the strategies designed by these firms to encourage customers to use their service for a longer span of time; (ii) the purposes that led them to their chosen fitness centers, in order to identify the most important areas on which the firm should focus to optimize its service quality; (iii) the customers' perspectives on service quality based on their assessment of the tangible and intangible products offered by the firms; and (iv) the link between service quality and customer satisfaction and customer retention. Interviews were also conducted to collect qualitative data to fill gaps in the analysis. The same sample respondents were interviewed for this purpose.

\subsection{Data analysis}

3.1.1. Visiting Frequency: Responses on the frequency of using fitness centers were addressed graphically by assessing the interquartile range (IQR) with a cumulative frequency analysis.

3.1.2. Visiting Purpose: The study assessed customer responses about the reason for visiting a fitness center by determining the importance customers gave to the three main purposes of their visits - wellness, wellbeing and socialization - with the following parameters: (i) wellness (to minimize issues related to specific illnesses: diabetes; hypertension; high cholesterol levels); (ii) wellbeing (stress reduction; confidence building; physique; weight loss; maintaining fitness); and (iii) socialization (engaging with family; interacting with friends; feeling good and relaxation). Cohen's $d$ was applied to identify gender differences in respondents' perceptions of their purpose for visiting the fitness center. The effect size was adopted as a benchmark to assess the level of similarity in the perceptions of male and female respondents. A small effect size of $d=0.20$ indicated 85 percent similarity and was considered acceptable in this study, as suggested in the research by Cohen (1988).

3.2.3. Service Quality: As mentioned in the literature review, several factors have been recommended by researchers for measuring the service quality in industry in general. The present study was based on a pilot survey conducted in 2018 with 50 respondents randomly selected from one non-hotel-based fitness center operating in Abu Dhabi city, as a result of which the determinants for assessing customers' perception of service quality were categorized into six major factors with following variables. They are: (i) personnel (staff friendliness; trained skill; and empathy towards customers); (ii) physical (space adequacy and modernity of layout, with modern and good equipment; hygiene; location convenience; and better amenities, such as showers, lockers, changing room); (iii) social (brand reputation; impact of customer population; friendly and social customer groups; various fitness challenges; and safety in the center); (iv) support (motivating promotion programs; childfriendly atmosphere; up-to-date communication about new products/services; customized and convenient timing; affordable membership price and training price) and (v) program (free training and programming; variety of group classes; and wide range of programs); and (vi) outcomes (supportive to achievement of fitness goals; and value for the price). Customers responses to the six determinants were assessed by collecting their perceptions on variables related to the five determinants (given in parentheses above) using a five-point scale. The responses were evaluated with the aid of factor analysis. Cronbach's alpha was used to assess the reliability of the data. The Kaiser-Meyer-Olkin test was also applied to measure the sample adequacy.

Bartlett's test of sphericity was used for a significance test. The interconnection between the variables, as well as their relationship to the service quality, were assessed with the help of a rotated component matrix. The significant influence of the selected variables on service quality and customer satisfaction was assessed with the Binary Logistic Regression Model (BLRM), which was also applied to estimate the influence that the independent variables had on the "odds ratio." The result of BLRM was validated by omnibus tests with $\mathrm{p}=<0.05$.

The correspondence analysis of service quality with customer satisfaction assessed the level of customers' perception of the variables that determine service quality with customer satisfaction. A regular Markov chain was used to analyze the customer retention level in the sample firms based on the service quality and customer satisfaction results. Therefore, the service quality index (SQI) and customer satisfaction levels derived from primary data analysis were used to develop the transition matrix for the probability of respondents retaining or not retaining membership with the firms. The survey responses of customers on their intention to remain or not to remain as members of their fitness centers were transferred into a state matrix to identify the year when the matrix becomes stationary, at which point the firms have to design strategies to improve current service quality and to understand the percentage of current members that will remain as loyal customers. 


\section{Results and Discussion}

\subsection{Profile of the customers}

The basic profile of the fitness firm users is valuable in identifying a matrix hierarchy, and this is well explicated with age and gender. The age of the customers indicates a highly flat normal density, as 70.4 percent of respondents were aged 23-38 years, with a wide dispersion with other age groups. This shows that the users of the fitness firms were young employed groups and that those aged less than 22 and over 55 were thinly represented. Therefore, age-wise analysis was not included in this study. Slightly more females (52 percent) than males used the fitness firms. This is important for the industry focus and promotional activities, and a gender-wise analysis was considered.

\subsection{Fitness profile}

The fitness profile of the respondents was examined to know the frequency of using fitness centers. Fig. 1 shows a median of 120 minutes (two hours) spent by 50 percent of the customers in the centers. With the time spent in a fitness center ranging from a lower duration of 95 minutes to an upper duration of 165 minutes, and an IQR showing that 70 minutes were spent by the respondents in the fitness center, an average of $30(<50$ percent of $n)$ respondents fall in the IQR given in Fig. 1.

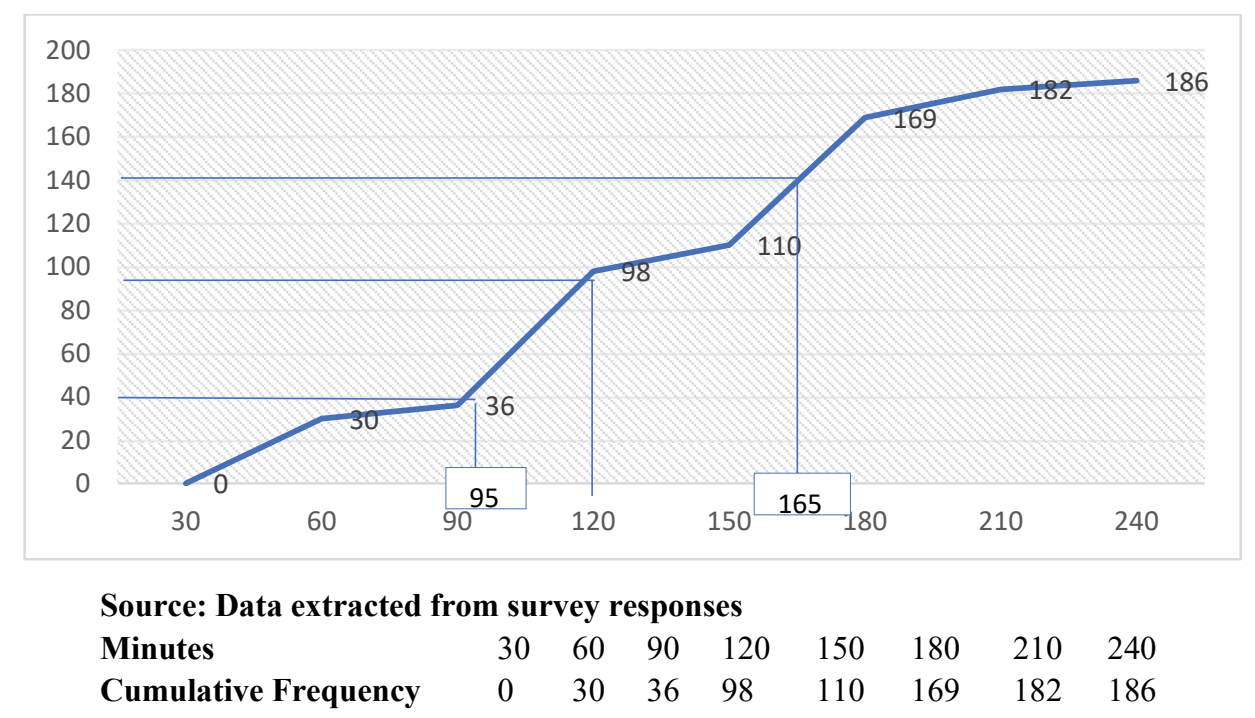

Fig. 1. Time spent by the respondents in the fitness center (in minutes)

\subsection{Purpose of visiting fitness center}

The reasons for using the fitness centers, as perceived by the customers, varied. Considering the gender differences, Table 1 indicates a very small difference between males and females in the perception of using fitness centers.

Table 1

Purpose of visit

\begin{tabular}{|c|c|c|c|c|}
\hline Parameters & Variables & Male & Female & $D$ \\
\hline \multirow[t]{4}{*}{ Wellness } & Illness concern & 0.61 & 0.74 & +0.31 \\
\hline & Diabetic issue & 0.49 & 0.46 & +0.06 \\
\hline & Blood Pressure & 0.63 & 0.59 & +0.09 \\
\hline & Cholesterol & 0.64 & 0.62 & +0.05 \\
\hline \multicolumn{5}{|l|}{ Well-being } \\
\hline & Stress reduction & 0.75 & 0.81 & +0.16 \\
\hline & Physic building & 0.81 & 0.92 & +0.35 \\
\hline & Weight reduction & 0.91 & 0.89 & +0.06 \\
\hline & Overall fitness & 0.99 & 0.11 & +0.18 \\
\hline & Develop confidence & 0.86 & 0.91 & +0.18 \\
\hline \multicolumn{5}{|l|}{ Socializing } \\
\hline & Engage with friends & 0.50 & 0.48 & +0.04 \\
\hline & Engage with family & 0.48 & 0.45 & +0.06 \\
\hline & For Relaxation & 0.67 & 0.81 & +0.36 \\
\hline & Feel happy & 0.97 & 0.93 & +0.20 \\
\hline
\end{tabular}

Note. Positive values of $\mathrm{d}$ represent higher scores for men; negative values of $\mathrm{d}$ represent higher scores for women Source: Primary survey

Considering the high mean and low effect size, respondents' purpose for visiting the fitness centers was to reduce stress, lose weight, improve fitness and develop confidence and happiness. Wellbeing is the most important purpose in the matrix presented in Fig. 2, with a low significance associated with socializing. 


\subsection{Perception of service quality and customer satisfaction}

The customers' fitness level and satisfaction were governed to a great extent by the services offered by the fitness firms; hence, for measuring customer satisfaction and loyalty to the firms, it is imperative to assess the service quality. To identify respondents' perception of the selected six indicators (personnel, physical, social, support, program, and outcomes), their responses to the 18 statements linked to these six indicators were marked using a five-point scale.

\begin{tabular}{l|l|l|l|}
$\begin{array}{l}\text { Mean } \\
\text { High }\end{array}$ & $\begin{array}{l}\text { For Stress \& Weight reduction; } \\
\text { Fitness; Confidence; Happiness }\end{array}$ & $\begin{array}{l}\text { To: feel relaxed; physic } \\
\text { building retain health }\end{array}$ & \\
\cline { 2 - 4 } Low & $\begin{array}{l}\text { Control: Diabetic; Blood pres- } \\
\text { sure; Cholesterol }\end{array}$ & & \\
\cline { 2 - 4 } Effect size & $\begin{array}{l}\text { To engage with friends and } \\
\text { family }\end{array}$ & & Large \\
\cline { 2 - 4 } & \multicolumn{2}{|c|}{ Small Medium } & \\
\end{tabular}

Fig. 2. Priority for visiting fitness center; mean and effect size for male vs female.

The personnel attribute was appraised with the aid of three statements relating to the assessment of services offered by the staff and trainers of the fitness firms. Six statements relating to amenities and other facilities in the gym were used to record customers' perception of the physical service quality. The social attribute of the service quality was measured by using three statements relating to the social atmosphere. Support service quality included the service quality of additional facilities/services and information. Program service quality was measured using two statements, and outcome service quality incorporated one statement. The average score of the statements in each indicator was computed and the Likert scale results of the same are shown in Table 2. Most of the indicators were ranked as high or very high by the majority of the customers. However, for support and program, 30 percent of respondents gave a moderate ranking, whereas for other attributes this figure is closer to 20 percent. Also, the number of those who gave low or very low scores for these two attributes is high compared to the other attributes. Overall, the service quality assessment score was calculated by aggregating and averaging the six indicators of service quality. The results show that 17.8 percent of respondents rated the overall service quality index (SQI) as very high, but that most respondents rated it as high (50.3\%), with $29.2 \%$ of respondents rating it as moderate (see Table 2 ).

Table 2

Perception on Service Quality

\begin{tabular}{lccccccc}
\hline & Outcome & \multicolumn{1}{c}{ Program } & Support & Social & Physical & Personnel & SQI \\
\hline Very High & 28.6 & 17.8 & 16.2 & 22.9 & 27.6 & 33 & 17.8 \\
High & 46.5 & 40.5 & 34.1 & 49.13 & 43.8 & 41.6 & 50.3 \\
Medium & 20.82 & 29.2 & 30.3 & 23.89 & 23.2 & 21.1 & 29.2 \\
Low & 3.89 & 10.8 & 15.1 & 3.89 & 3.8 & 3.4 & 1.1 \\
Very low & 0.19 & 1.7 & 4.3 & 0.19 & 1.6 & 0.9 & 1.6 \\
\hline
\end{tabular}

Source: Primary survey

To further recognize the major factors from the statements relating to the service quality, the statements were evaluated with the aid of Factor Analysis. Cronbach's alpha was used to assess the reliability of the data; a value of 0.949 indicated a strong data consistency. A value of 0.925 on the Kaiser-Meyer-Olkin test showed the sample's adequacy (see Table 3). Bartlett's test of sphericity was also significant.

Table 3

Reliability Statistics and KMO and Bartlett's Test

\begin{tabular}{lll}
\hline Reliability Statistics - Cronbach's Alpha & & \\
\hline Kaiser-Meyer-Olkin Measure of Sampling Adequacy. & & .949 \\
& Approx. Chi-Square & .925 \\
Bartlett's Test of Sphericity & Df & Sig. \\
& S664.200 & 153 \\
\hline
\end{tabular}

Three factors with an Eigenvalue higher than 1 were extracted, and these are shown in the rotated component matrix in Table 4. The first factor has eight statements, from which six relate to the physical attributes of the service quality. One statement relating to each social and outcome service quality also found a place in the first factor. The second factor has six statements. Along with the three statements relating to the personnel service quality, the second factor has social, physical and outcome attributes. The physical and outcome service quality statements in the first factor also found a place as the second factor. These two statements related to a safe environment at the gym, which is a physical factor, and to the ability to achieve one's fitness goals, which is a statement relating to the outcome attribute of service quality. Three statements relating to the support attribute of the service quality and one statement relating to the program service quality feature in the third factor. The overall results show the priority given to the physical and the outcome attributes by the customers, along with the staff behavior and the personalized attention received (see Table 4). 
Table 4

Rotated Component Matrix ${ }^{\mathrm{a}}$

\begin{tabular}{|c|c|c|c|}
\hline & & mpone & \\
\hline & 1 & 2 & 3 \\
\hline Class of Customers attending the Gym are good & .688 & .366 & .168 \\
\hline My club has adequate space & .770 & .262 & .177 \\
\hline My club has better amenities (showers, lockers, change rooms, etc) & .819 & .108 & .273 \\
\hline My club has modern facilities and equipment's & .783 & .195 & .245 \\
\hline My club is clean and hygienic & .725 & .280 & .317 \\
\hline My club offers facilities/programs that accommodates my kids & .081 & .204 & .835 \\
\hline My club offers wide range of attractive programmes & .269 & .338 & .805 \\
\hline My club provides me with up to date information regarding the products/service & .408 & .290 & .708 \\
\hline My club supplies nutritional products and health supplements & .319 & .132 & .701 \\
\hline My Club program timings are convenient to me & .424 & .428 & .354 \\
\hline Number of customers do not affect the service offered to me & .451 & .455 & .416 \\
\hline Other customers are friendly and interactive with me & .329 & .584 & .314 \\
\hline Staff are friendly and polite & .266 & .878 & .135 \\
\hline Staff are well trained & .366 & .801 & .250 \\
\hline Staff give me personal attention & .138 & .768 & .388 \\
\hline The club's overall environment is Safe & .647 & .567 & .085 \\
\hline The condition and availability of equipment in my club is good & .761 & .312 & .218 \\
\hline The equipment's and programs are helping me to achieve my fitness goal & .569 & .527 & .325 \\
\hline
\end{tabular}

More emphasis was given by the customers on a safe atmosphere and the ability to achieve fitness goals by working out at the gym. It was also notable that the customers rated the amenities, facilities, exercise equipment and hygiene as good. In terms of the availability of trained and well-behaved personnel, the customers also rated their gyms positively. One factor of concern was the large number of customers: according to the respondents, this affected the service they received. During peak times, they felt that there was a slight decline in the services offered (interview, August 2019). Factor analysis of the customer assessment of the service quality of the fitness firms shows valid inferences as customers gave good ratings for the service quality indicators. Furthermore, a comparison of the factor analysis values with the customer satisfaction data reveals that more than 70 percent of the customers were satisfied or moderately satisfied with their present gym use, and that 18.9 percent of the customers were highly satisfied. The dissatisfaction rate was less than 10 percent. Hence, both results show close congruency between very high SQI scores and high satisfaction. In addition, Fig. 3 presents the Correspondence Analysis of service quality with customer satisfaction, revealing that the perception of the customers about the service quality determines their satisfaction level with the present gym.

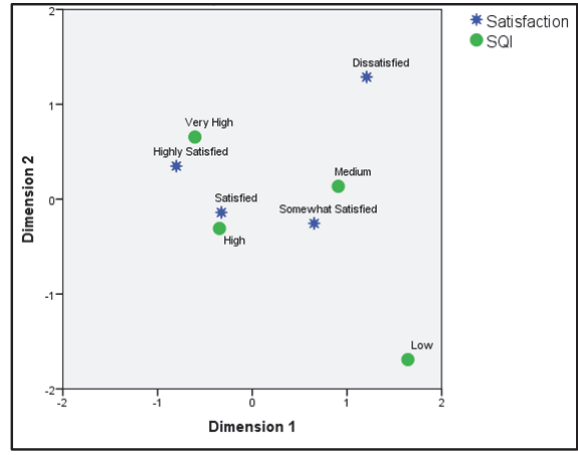

Source: Primary Survey

Fig. 3. Correspondence Analysis of Service Quality and Customer Satisfaction Row and Column Points-Symmetrical Normalization

To further interpret the result in Fig. 3, the BLRM was applied to assess the significance of overall service quality based on an evaluation of the personnel, physical, social, support, program and outcome variables. The BLRM estimates the influence of the independent variable on the "odds ratio", which is the probability of the event divided by the probability of the nonevent. From Tables 5(a) and 5(b), it is evident that the model is statistically significant. In addition, the omnibus tests to evaluate the performance of the model based on its $P$ value of 0.000 and Chi-Square statistics show 179.960 in Table 5(b). Based on this, it is inferred that the model is statistically significant.

As Table 6 shows, the personnel, physical, social, support and outcome variables are significant. Therefore, it can be concluded that these variables significantly influence the overall service quality of the fitness firms. 
Table 5

Binary Logistic Regression

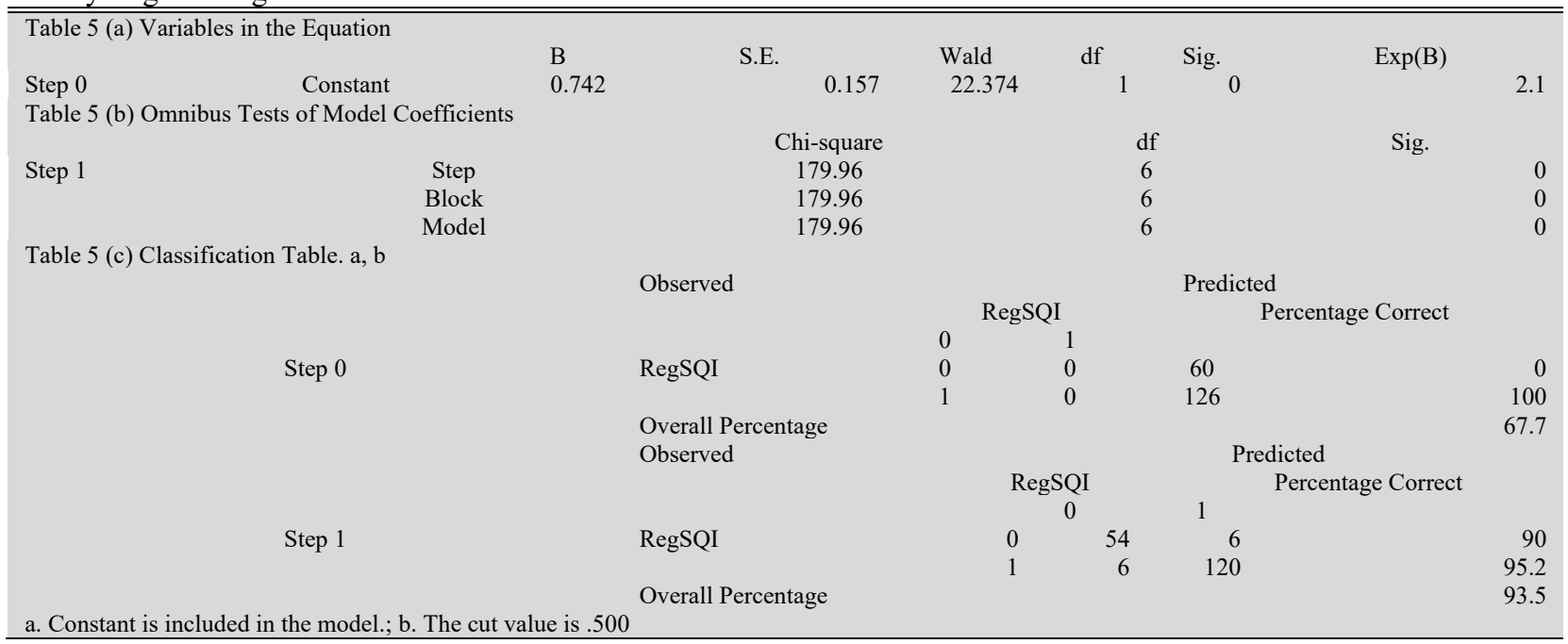

Table 6

Variables in the Equation

\begin{tabular}{|c|c|c|c|c|c|c|c|}
\hline & & $\mathrm{B}$ & S.E. & Wald & Df & Sig. & $\operatorname{Exp}(B)$ \\
\hline \multirow{7}{*}{ Step $1^{\mathrm{a}}$} & RegPer & 4.099 & .951 & 18.587 & 1 & .000 & 60.278 \\
\hline & RegPhy & 3.484 & .855 & 16.618 & 1 & .000 & 32.583 \\
\hline & RegSoc & 1.515 & .737 & 4.223 & 1 & .040 & 4.550 \\
\hline & RegSup & 1.526 & .811 & 3.540 & 1 & .060 & 4.601 \\
\hline & RegProg & 1.204 & .780 & 2.380 & 1 & .123 & 3.333 \\
\hline & RegOut & 1.637 & .936 & 3.064 & 1 & .080 & 5.142 \\
\hline & Constant & -7.629 & 1.625 & 22.043 & 1 & .000 & .000 \\
\hline
\end{tabular}

a. Variable(s) entered on step 1: RegPersonnel, RegPhysical, RegSocial, RegSupport, RegProgramme, RegOutput.

\subsection{Customer retention state}

To ascertain the trend of customer retention, respondents' willingness to renew their membership of their current fitness center was analyzed. As Table 7 shows, 69.5 percent of respondents confirmed their renewal of membership, while 29.5 percent were not sure about the renewal of membership with their current fitness center based on their perceptions of service quality and customer satisfaction rate.

Table 7

Renewing membership with respondents' current fitness centers

\begin{tabular}{lll} 
& Surely renew & Not sure to renew \\
\hline$\%$ of respondents & 69.5 & 30.5 \\
\hline
\end{tabular}

A regular Markov chain was applied to examine the stationary matrix and steady state in customer retention by selecting the SQI and customer satisfaction rate. The SQI rates of very high and high were summed up to 0.68 , and the SQI rates of medium, low and very low were summed up to 0.32 . Customer satisfaction was .90 and not satisfied was .10. With these data, the probability of renewing membership (RM) or not renewing membership (NRM) were ascertained by developing the following transition matrix:

$$
\begin{array}{lllr} 
& & \text { RM } & \text { NRM } \\
\text { Transition matrix } & P & \text { RM } & \left|\begin{array}{ll}
.68 & .32 \\
.90 & .10
\end{array}\right|
\end{array}
$$

The respondents' view on renewal or not renewal of membership was selected from Table 8 . Therefore, the current state of the matrix was approximately:

$\mathrm{S}_{0}=[.70 .30]$, then,

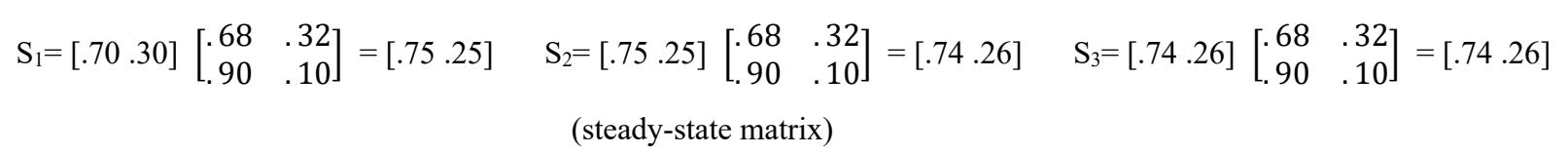

The state matrix $S_{3}$ indicates a 6 percent increase in membership from $S_{1}$. By the second and third year, however, the state matrices were getting closer $\left(S_{2}=S_{3}\right)$. So, with a stationary matrix of [.74 .26] in the third year, the system was found to be at a steady state, indicating no further improvement in the retention of customers without an improvement in the current state 
of the SQI and customer satisfaction rate. This implies that service quality leads to customer satisfaction and that both lead to customer retention.

\section{Conclusion}

This study finds that increasing participation of the young generation and the absence of gender bias would bring a growing customer profile to the fitness sectors. It is also equally valid to infer that the major motivating factors for using fitness centers are consistently the attainment of wellbeing followed by wellness. For instance, the intensity of the usage of fitness services (time spent in a fitness center) showed an average of 70 minutes spent by the respondents in the fitness center, which was $\mathrm{n}=$ $30<50$ percent of sample and was in an IQR of 95 to 165 minutes. This issue needs attention in order to improve customers' satisfaction levels. The assessment of the service quality of the fitness firms showed valid inferences as more than 70 percent of customers were satisfied or moderately satisfied with their present services, and this result revealed close congruence between a very high SQI score and highly satisfied customers. This indicates that service quality results in customer satisfaction, and that these two factors are also an important driving force for customer retention. The Markov analysis projects a 6 percent increase in customer retention from 2019 to 2020. However, after 2020, the customer retention rate remains steady, indicating that unless there is an effort to improve the service quality index and customer satisfaction rate, the chance to improve memberships are limited in the fitness centers. Therefore, this study suggests that without further improvements in the marketing mix and focusing on both tangible and intangible products, customer retention would be affected. A business can only be successful if it constantly satisfies its customers and expands its customer profile by retaining customers and attracting potential new customers to the business. In an economically slowing market, the fitness sector in Abu Dhabi is facing challenges, particularly due to fierce competition arising from the entry of new players with attractive packages into the market. Hence, it is paramount that fitness centers meet the expectations of their member-customers and try to reach out to potential customers. Despite the limitation of focusing only on member-customers, the literature, methodology and findings of this paper can support further research in this field.

\section{References}

Abbas, W. (2019). Cost of living to decline in UAE on falling rents, lower oil, available at: https://www.khaleejtimes.com/business/economy/Cost-of-living-to-decline-in-UAE-on-falling-rents-lower-oil

Algethami, S. (2013). Why the UAE is a leading tourism destination in the region, available at: https://gulfnews.com/business/tourism/why-the-uae-is-a-leading-tourism-destination-in-the-region-1.1261536

Asubonteng, P., McCleary, K.J. \& Swan, J.E. (1996). SERVQUAL revisited: A critical review of service quality. The Journal of Services Marketing, 10(6), 62-81.

Caruana, A. (2002). Service loyalty: The effects of service quality and the mediating role of customer satisfaction. European Journal of Marketing, 36 (7/8), 811-28, DOI: 10.1108/03090560210430818.

Chang, K. \& Chelladurai, P. (2003). System-based quality dimensions in fitness services: Development of the scale of quality. The Service Industries Journal, 23(5), 65-83.

Chelladurai, P., Scott, F.L. \& Haywood-Farmer, J. (1987). Dimensions of fitness services development of a model. Journal of Sport Management, 1(2), 159-72.

Cohen, J. (1988). Statistical Power Analysis for the Behavioral Sciences (2nd ed.), Lawrence Erlbaum Associates, Hillsdale, NJ. Available at: https://www.scirp.org/ (S(lz5mqp453edsnp55rrgjct55))/reference/ReferencesPapers.aspx?ReferenceID=2041144

Daniel, C.N., \& Berinyuy, L.P. (2010). "Using the SERVQUAL Model to Assess Service Quality and Customer Satisfaction: An Empirical Study of Grocery stores in Umea", available at: http://www.diva-portal.org/smash/get/diva2:327600/fulltext01

DOTW news (2017), “The unstoppable rise of spa and wellness Travel in the UAE", Destinations of the World News, available at: https://news.mb.com.ph/2018/03/05/baguio-posts-1-7-million-tourist-arrivals-in-2017/

Douglas, L. \& Connor, R. (2003). Attitudes to service quality: The expectation gap. Nutrition and Food Science, 33(4), $165-72$.

Dubai Economy. (2018). Dubai Economy Report, available at: http://www.dubaided.ae/ StudiesAndResearchDocument/Dubai-Economic-Report-2018-Full-Report.pdf

Dupuis, P. (2019). Will the approaching recession bury your fitness business? available at: http://www.petedupuis.com/blog1/2019/7/25/will-an-approaching-recession-bury-your-fitness-business

Economic Times (2016). Perceived Valuing Price. 13 April, p. 1, available at: https://economictimes.indiatimes.com/p/perceivedvalue-pricing/articleshow/51807284.cms? from $=\mathrm{mdr}$

Eshghi, A., Roy, S.K. \& Ganguli, S. (2008). Service quality and customer satisfaction: An empirical investigation in Indian mobile Telecommunications services. Marketing Management Journal, 18(2), 119-44.

Feigenbaum, A.V. (1986). Total Quality Control, McGraw-Hill, New York.

Ferguson, R. \& Brohaugh, B. (2008). Telecom's search for the ultimate customer loyalty platform. Journal of Consumer Marketing, 25(5), 314-318, available at: http://dx.doi.org/ 10.1108/0736760810890543

Global Wellness Institute (2016). Report on future wellness, available at: https://globalwellnessinstitute.org/global-wellness-institute-blog/2016/02/23/2016-2-23-global-wellness-institute-releases-reports-on-workplace-wellness-programs-will-give-way-toreal-company-caring-and-culture-change/

GMI (2019). UAE population statistics, available at: https://www.globalmediainsight.com/ blog/uae-population-statistics/

Gonçalves, C, Biscaia, R., Correia, A. \& Diniz, A. (2014). An examination of intentions of recommending fitness centers by user members. Rio Claro, 20(4), 384-91. 
IMTJ. (2015). Euromonitor international reveals that the UAE spa market is booming, available at https://www.imtj.com/news/euromonitor-international-reveals-uae-spa-market-booming/

Jobber, D. \& Chadwick, F.E. (2016). Principles and Practice of Marketing (UK Higher Education Business Marketing), McGrawHill Education, London, pp. 564-87.

Juran, J.M. \& Godfrey, A.B. (1999). Juran's Quality Handbook, McGraw-Hill, New York.

Kaul, S. (2005). Measuring Retail Service Quality: Examining Applicability of International Research Perspectives in India. Working Paper (2005-10-02), Indian Institute of Management, Ahmedabad.

Kerr, S. (2019). Dubai fears the end of its 'Build it and they will come' model, available at: https://www.ft.com/content/4d169d0c4be4-11e9-8b7f-d49067e0f50d

Ko, Y.J. \& Pastore, D.L. (2004). Current issues and conceptualizations of service quality in the recreation sport industry. Sport Marketing Quarterly, 13(3), 158-66.

Kotler, P., \& Keller, K.L. (2016). Marketing Management: Global Edition, Pearson Education, Harlow, pp. 483-95.

Lam, E.T.C., Zhang, J.J. \& Jensen, B.E. (2005). Service quality assessment scale (SQAS): An instrument for evaluating service quality of health-fitness clubs. Measurement in Physical Education and Exercise Science, 9(2), 79-111.

Ma, Y. (2011). Current situation and countermeasures of fitness clubs industry of Shadong Province. International Journal of Business and Management, 6(5), 228-30.

Mahalakshmi, V., \& Saravanaraj, M. (2011). An empirical study on customer's satisfaction towards banking services in Trichy. Interdisciplinary Journal of Contemporary Research in Business, 3(4), 237-53.

McGroarty, B. (2017). New research: The fastest growing Middle East/north Africa wellness tourism markets, available at: https://globalwellnessinstitute.org/press-room/press-releases/new-data-released-at-wttc-indicanew-research-the-fastest-growing-middle-east-north-africa-wellness-tourism-markets/

Nath, A. \& Zheng, L. (2004). Perception of E-service quality in E-commerce, available at: http://www.diva-portal.org/smash/get/diva2:1018947/FULLTEXT01.pdf.

Nitin, S., Deshmukh, S.G., \& Vrat, P. (2005).Service quality models: A review. International Journal of Quality and Reliability Management, 22(9), 913-49.

Nuseir, M.T., \& Madanat, H. (2015). 4Ps: A strategy to secure customers' loyalty via customer satisfaction. International Journal of Marketing Studies, 7(4), 78-87.

Parasuraman, A., Zeithaml, V.A., \& Berry, L.L. (1985). A conceptual model of service quality and its implications for future research. Journal of Marketing, 49, 41-50.

Parasuraman, A., Zeithaml, V.A. \& Berry, L.L. (1988). SERVQUAL: A multiple-item scale for measuring consumer perceptions of service quality. Journal of Retailing, 64(1), 12-39.

Prentice, C. (2013). Service quality perceptions and customer loyalty in casinos. International Journal of Contemporary Hospitality Management, 25(1), 49-64

Pride, W.M. \& Ferrell, O.C. (2012). Marketing, South-Western College, 16 ed, South-Western Cengage Learning, Ohio, pp. 1-113.

Rahman, S. (2012). A year that will go down in UAE history for economic recovery, available at: https://gulfnews.com/business/ayear-that-will-go-down-in-uae-history-for-economic-recovery-1.1097075

Reza, D., Shahin, A., Saljoughian, A. \& Shirouyehzad, H. (2016). Importance-performance analysis of service quality dimensions for the customer groups segmented by DEA. International Journal of Quality and Reliability Management, 33 (2), 160-77.

Ruseva, R., \& Ruskov, P. (2015). An application of a customer-centric innovation approach in the health industry: The case for video streaming in group fitness classes in German fitness centers, IEEE International Conference on Engineering, Technology and Innovation/International Technology Management Conference (ICE/ITMC) 13-15 June 2015, Norway.

Saravanan, R., \& Rao, K.S.P. (2007). Measurement of service quality from the customer's perspective: An empirical study. Total Quality Management, 18(4), 435-49.

Sidin, S., Rashid, M.D.Z.A. \& Zainal, R.A.R.R. (2001). Measuring customers' perceived service quality in hotel industry. University Putra Malaysia Press, 9(2), 71-85.

Sokhan, O.K., Suy, R., Chhay, L., \& Choun, C. (2018). Customer satisfaction and service quality in marketing practices: Study on literature review. Asian Themes in Social Science Research, 1, 21-27.

Sureshchandar, G., Rajendran, C. \& Anantharaman, R. (2002). The relationship between service quality and customer satisfaction: A factor specific approach. Journal of Services Marketing, 16 (4), 363-79.

Thompson, M. (2019). Description of how marketers can use Maslow's hierarchy of needs, available at: https://smallbusiness.chron.com/description-marketers-can-use-maslows-hierarchy-needs-39333.html

Wisniewski, M. (2001). Using SERVQUAL to assess customer satisfaction with public sector services. Managing Service Quality: An International Journal, 11, 380-88. https://doi.org/10.1108/EUM0000000006279

Yildiz, S.M. (2011). An importance-performance analysis of fitness center service quality: Empirical results from fitness centers in Turkey. African Journal of Business Management, 5(16), 7031-41.

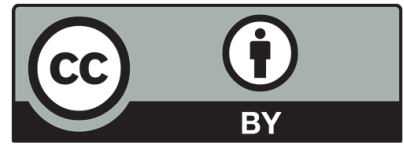

(C) 2020 by the authors; licensee Growing Science, Canada. This is an open access article distributed under the terms and conditions of the Creative Commons Attribution (CC-BY) license (http://creativecommons.org/licenses/by/4.0/). 